\title{
Lumen
}

Selected Proceedings from the Canadian Society for Eighteenth-Century Studies

\section{'Do you understand muslins, Sir?': the Circulation of Ball Dresses in Evelina and Northanger Abbey}

\section{Jackie Reid-Walsh}

Volume 19, 2000

Material Productions \& Cultural Construction

Culture matérielle \& Constructions discursives

URI : https://id.erudit.org/iderudit/1012326ar

DOI : https://doi.org/10.7202/1012326ar

Aller au sommaire du numéro

Éditeur(s)

Canadian Society for Eighteenth-Century Studies / Société canadienne d'étude du dix-huitième siècle

ISSN

1209-3696 (imprimé)

1927-8284 (numérique)

Découvrir la revue

Citer cet article

Reid-Walsh, J. (2000). 'Do you understand muslins, Sir?': the Circulation of Ball Dresses in Evelina and Northanger Abbey. Lumen, 19, 215-223.

https://doi.org/10.7202/1012326ar

Copyright (c) Canadian Society for Eighteenth-Century Studies / Sociéte canadienne d'étude du dix-huitième siècle, 2000
Ce document est protégé par la loi sur le droit d'auteur. L'utilisation des services d'Érudit (y compris la reproduction) est assujettie à sa politique d'utilisation que vous pouvez consulter en ligne.

https://apropos.erudit.org/fr/usagers/politique-dutilisation/ 


\section{5. 'Do you understand muslins, Sir?': the Circulation of Ball Dresses in Evelina and Northanger Abbey.}

Evelina and Northanger Abbey relate histories of young women entering society. Since Evelina and Catherine both arrive in fashionable centres from the country, some of the action in the novels concerns the outfitting of the heroines and their chaperons in appropriate apparel, and then their appearing at assemblies, private balls, and other social events. Accordingly - unlike other fiction by Frances Burney and Jane Austen - these novels contain descriptions of women shopping for clothes and selecting specific clothes to wear to certain functions, as well as of their attending these events. When the dates of the novels' composition are considered, ${ }^{1}$ a comparative study of the attention to fashion and the consumption of fashion becomes possible since the period between the mid-1770s and 1803 has been documented by historians as one in which a reversal of style and materials occurred, especially in ball gowns. In the earlier years, ball gowns were tight in the bodice, had full skirts, and were elaborate and extravagant in relying on sumptuous silks and satins; by 1803 , high waisted, narrow dresses were simple in style, their fabrics light-weight muslins and gauzes (Bradfield 86).

This paper combines research in social history with a theoretical approach derived from studies in material culture. Since ball dresses as material artifacts are 'mute,' the texts of Burney and Austen are not read in terms of literary explication but as fictive ethnographies of behaviour (Miller 12), providing accounts of women as consumers and wearers of fashionable evening clothes. I focus on the circulation of women's fashion with special reference to ball dresses of the 1770 s and 1800 s, employing the term 'circulation' in a double sense. On one hand, I study ball dresses in the two periods as commodities or 'circulating objects' which women purchase for themselves and thereby circulate within a market economy. On the other, I am interested in the ball dresses of the two periods as representing a circulation of fashion from one style to another. This fashion shift has been well documented by contemporary onlookers who saw ball dresses as 'public objects' that reveal attributes of the society. ${ }^{2}$ Specifically, I am interested in the significance of shifts in fabric 
and style during the period. Ultimately, I explore connections between ball dresses as 'circulating objects' and 'interpreted objects' (Corrigon $441-42,436)$ and whether women's roles in the former offer insights into the latter. Particularly relevant here is who is considered a 'competent' observer of fashion in society (Corrigon 440, n447).

\section{The Circulation of Silk in the 1770s}

We have been a shopping as Mrs. Mirvan calls it, all this morning, to buy silks, caps, gauzes, and so forth. The shops are really entertaining, especially the mercers; there seem to be six or seven men belonging to each shop; and every one took care by bowing and smirking, to be noticed. We were conducted from one to the other, and carried from room to room with so much ceremony, that at first I was almost afraid to go on.

I thought I should never have chosen a silk; for they produced so many, I knew not which to fix upon; and they recommended them all so strongly, that I fancy they thought I only wanted persuasion to buy every thing they showed me. And, indeed, they took so much trouble, that I was almost ashamed I could not. (Evelina, vol 1,21)

Here Evelina describes and dissects the new culture of 'a shopping.' Like an anthropologist visiting unfamiliar territory and people, she is a participant-observer giving us a brief but incisive description of people in the London shops. She describes the absurd ceremony of visiting mercers for silks, then milliners for caps and ribands. In each shop she observes with dry humour the affected behaviour of the male sales clerks, who seem 'to understand every part of a woman's dress better than we do ourselves, ... they recommended caps and ribands with an air of so much importance' that she 'wished to ask them how long they had left off wearing them.' For their part, the women shoppers are so highly dressed that they appear to be visiting, not making purchases. Moreover, the women are treated as if royalty, the fabrics and trimmings being feasts for their consumption. Evelina notes as well how the clerks try to persuade women to buy more than they need. She observes the tremendous speed with which the clothes are made, commenting that the shopkeepers promise a fully made set of garments or 'suit of linen' for the same evening (vol 1,22).

Evelina's comments about the London shops and the prevalence of women customers from the middling classes accord with the research of economic historian Neil McKendrick, who, with John Brewer and J.H. Plumb in The Birth of a Consumer Society (1982), draws upon numerous first-hand accounts by shoppers and travellers. Evelina's comments 
confirm this research. What I find unusual in Evelina's description is the women-centred view of her account which places the shopping excursion squarely into gender (and class) power relations; the middle class women through their purchasing power appear powerful figures over against the fawning lower class male clerks. Moreover, some women, if Evelina is typical, recognize the persuasive hyperbole of sales clerks and resist their blandishments, thereby demonstrating a healthy scepticism to sales techniques. This 'first hand' account of face-to-face sales technique complements what McKendrick observes about the lack of scruples in print advertising of the period.

Evelina's keen eye records no prices of materials but stresses the multitude of choices offered. In The Art of Dress: Clothes and Society 1500-1914 (1996), Jane Ashelford, a dress historian for the British National Trust, describes how, during the Eighteenth Century, shopping in London became an elegant leisure activity. In good establishments, price was not fixed but established by negotiation. Prices for silk fluctuated but were consistently high whether it was imported or made in England.

One reason for the high price was the intensive labour needed to produce raw silk: silk-throwers had to spin and wind it, and weavers had to make the fabric. ${ }^{3}$ Ashelford calculates that sack gowns popular in the mid-Eighteenth Century required between 20 and 22 yards of material, making the price of a silk gown between $£ 10$ to $£ 70$. Because of such high costs, whenever possible silk gowns from the mid-century were re-made in the 1770s when fashion changed.

Milliner prices were also high, their role becoming important when emphasis in fashion shifted to trimmings in the last quarter of the Eighteenth Century. Milliners also made aprons, handkerchiefs, ruffles, caps and head-dresses. Ashelford cites from the letters of Marchioness Grey who purchased 'a suit of point,' a set of lace, from Mrs. Beavois, a milliner, in 1780 , for $£ 56$. The price was similarly high at a lace shop, for in 1775 James Boswell bought a set of lace for his wife at a Mrs. Chancellor's in Duke Street for 30 guineas. The trimming could thereby cost more than the material (160-61).

\section{The Circulation of Muslin c.1800}

"[D]o take this pin out of my sleeve; I am afraid it has torn a hole already; I shall be quite sorry it if has, for this is a favourite gown, though it cost but nine shillings a yard."

"That is exactly what I should have guessed it, madam," said Mr. Tilney, looking at the muslin.

"Do you understand muslins, sir?" 
"Particularly well; I always buy my own cravats, and am trusted to be an excellent judge; and my sister has often trusted me in the choice of a gown. I bought one for her the other day, and it was pronounced to be a prodigious bargain by every lady who saw it. I gave but five shillings a yard for it, and a true Indian muslin." (Northanger Abbey vol 1, 28)

Although Northanger Abbey does not contain descriptions of the shopping excursions Catherine and Mrs. Allen undertake as part of the Bath morning ritual, shopping and prices of material are reiterated throughout the Bath sequence by Mrs. Allen. Since 'Dress was her passion' (vol $1,20)$, every aspect of the experience was of interest: the latest styles as well as the variety and quality of the various materials. This passion translates into a welter of information about price and properties of muslin which are validated by the sarcastic wit of the sartorially keen but financially limited Henry Tilney. It is he who notices whether a muslin will wash and sententiously mouths the statement that 'muslin always turns to some account or other' and 'can never be said to be wasted' (vol 1,28).

This emphasis on price and the variable quality of muslin is reinforced by Austen in her Letters. Indeed, her letters provide a wealth of factual detail about everyday consumption practices of the period. As Ashelford notes, regarding shopping for clothes, with a dress income of 20 pounds a year Austen had to be economical (170). Thus, on Thursday April 18, 1811, she records how she bought checked muslin for seven shillings a yard, and also that she brought ten yards of a pretty coloured muslin for Cassandra at 3s. 6d. per yard (268). Ten years earlier, Austen notes how expensive (and impractical) muslin dresses may be. Her sardonic eye observes the fashion of 'sheer undressing' (Lady's Monthly Museum June 1802 , qtd. in Bradfield 86) which was in vogue. Thus on a cold January night, she notes that 'Mrs. Powlett was at once expensively \& nakedly dress'd; we have had the satisfaction of estimating her Lace \& her Muslin; \& she said too little to afford us much other amusement' (Letters, Jan. 8 1801, 105).

This documentary evidence supports fashion researchers who hold that muslin, while thin, light-weight, and significantly washable, was perhaps deceptively uniform in appearance and price. There was a wide range of muslin fabrics: it could be either bought quite inexpensively when produced from English mills (often in Lancashire), or it could be imported, the finest coming from India - as Henry Tilney is well aware! ${ }^{4}$ 


\section{The Circulation of Fashion:}

\section{the Social Economics of Muslin versus Silk}

Information about the price range of muslin from the viewpoint primarily of female consumers contradicts statements by the moralists of the early Nineteenth Century. If their statements are accepted at face value, it would appear that all muslin was the same, that it was uniformly cheap, and that women from all strata of society dressed alike. Consider this retrospective critique in The Picture of the Change of Fashion by D.S.M. (1818):

While expensive silks were worn, they could not be attained by persons of small fortune, nor could mantua-makers and Milliners walk about the streets and carry their parcels in such a dress, but, when a few shillings could purchase a Muslin gown quite in the fashion, every woman could command one. Bare necks and arms cost nothing. (40)

It would appear that at the turn of the century a levelling effect was operating that was the mirror image of the situation in the 1770s. In Evelina's period, women of higher and lower ranks are similarly criticized for dressing alike but the social order is disturbed in a different way. Since women of different ranks may wear silk dresses, high-heeled buckled shoes and elaborate headdresses, they appear equally well-off to the onlooker, thereby erasing visible social distinctions (McKendrick, Brewer, and Plumb 59). Thus, the German traveller J.W. von Archenholz writes in 1787: 'The appearance of the female domestics will perhaps astonish a foreign visitor more than anything in London.' Not only were they 'well' and 'tastefully' dressed, 'clad in gowns well adjusted to their shapes,' but they 'even wear silk and satin' dresses (McKendrick, Brewer, and Plumb 58).

In Evelina there is evidence of confusion of rank due to dress: on one occasion, at Marylebone Gardens, Evelina mistakes prostitutes for ladies (vol 2, 194-95). On a previous occasion, she herself is mistaken for an actress at Vauxhall (vol 2, 163). Indeed, part of Evelina's harsh criticism of her cousins, the Branghtons, is that they are tradesmen's children trying to dress like the middle class, and thereby falsely aspiring to be members of a higher class. This is clear when the Branghton girls attend the opera dressed improperly ( $v o l 1,71)$ and display themselves in the shop when they are well-dressed (vol 2, 142). ${ }^{5}$

The critique of dressing 'up' and emulating the class above was commonly made by commentators in the period (Campbell 40, in Brewer and Porter). Historians such as McKendrick accept this theory of emulation. But Colin Campbell and Amanda Vickery in Consumption and the 
World of Goods critique its unitary assumptions and develop more nuanced ideas based on character types, gender and class to account for the phenomenon of dress imitation. Another historian of the clothing trade, Beverly Lemire in Dress, Culture, and Commerce: The English Clothing Trade before the factory 1660-1800, maintains that dressing above one's station was an major strategy for tradespeople in pursuit of customers. Since most interactions were based on face-to-face contact, appearing prosperous and genteel was essential. This extended to the women of the family as well (8). ${ }^{6}$

As already mentioned, the situation of fashion erasing class distinctions seems to work in the opposite direction in Austen's period: in the citation from The Picture of the Change of Fashion, 'mistress and maid' are still criticized for being dressed alike, but now both are dressed in an apparently inexpensive fashion. It would appear that a levelling of fashion has occurred which disturbed the class hierarchy in a different way - a kind of democratization of dress. Austen's limited personal resources evidence this, as does Catherine's in Northanger Abbey when she is given only ten guineas to spend $(1,19)$. Yet each was fashionably enough dressed at balls to be complimented by male onlookers. Austen makes this observation through a sardonic aside in Northanger Abbey while couching her economic point in mock moralistic language:

Dress is at all times a frivolous distinction, and excessive solicitude about it often destroys its own aim. Catherine knew all this very well; her great aunt had read her a lecture on the subject only the Christmas before; .... It would be mortifying to the feelings of many ladies could they be made to understand how little the heart of man is affected by what is costly or new in their attire; how little it is biased by the texture of their muslin, and how unsusceptible of peculiar tenderness towards the spotted, the sprigged, the mull or the jackonet .... No man will admire her the more... Neatness and fashion are enough .... (Vol 1, 74)

This appearance of uniformity in fabric quality would be belied to knowledgeable 'insiders' - perceptive and knowledgeable shoppers such as Mrs. Allen and Henry Tilney. As Mckendrick observes, in a society where the pursuit of fashion is fuelled by class emulation, fine distinctions in dress survive to distinguish the higher priced from the lower priced garments, although they may appear less obvious to contemporary observers than to modern eyes (56-57). Yet contemporary shoppers (mainly women) would be experts in noting fine distinctions that would not be apparent to others - either the male moralist and traveller, or the typical male onlooker at a ball.

As McKendrick takes the words of poets and wits belittling women and fashion, not as indexes of consumer behaviour, but as expressions 
of the attitudes of their period (39), so I read the descriptions of moralists, and travellers similarly. Writings by moralists are not de facto descriptions of reality but attitude and description combined. Their writings may also contain an element of Utopian thinking that desires gender and class distinctions to be demarcated by dress, as noted by Peter Corrigon in his discussion of representative historical texts interpreting clothing (436-40). Such onlookers decry the status quo according to an idealized vision. Yet anthropological 'outsiders' in terms of knowledge, such onlookers are usually considered socially 'competent' members of society who are qualified to pronounce on the interpretation of dress (Corrigon 440, n447). On the contrary, the truly 'competent' interpreter is the woman consumer who knows fabrics and styles through purchasing and wearing garments.

In this paper I have combined a theoretical perspective derived from material culture studies with social history. By using literary texts as my primary source of information, I have employed Evelina and Northanger Abbey to provide glimpses into the behaviour of women from the middling classes in the later 1770s and early 1800s when shopping for fabrics and wearing fashionable garments to various events. My focus has been primarily on ball dresses because the shift in fashion was most evident in terms of their appearance and fabric. I interpret information in the novels about female consumption to indicate that the women in this span of years were knowledgable consumers. I argue that this insight, while not recognized as important knowledge, gives them a form of 'expert' or 'inside' knowledge about the social implications of dress in the period.

From examining the shifts in materials and style, I detect a 'circulation' from a fashion-levelling based on appearance of wealth through wearing silks and expensive materials in the 1770s, to one based on the wearing of relatively inexpensive muslin in the early 1800s. Ultimately, I suggest that this trajectory towards an apparent democratization of fashion fabric is not as direct a line as it first appears, but that fine distinctions in dress remained to mark class and wealth. As Austen ironically notes, it was a commonplace among moralists to preach that 'dress is a frivolous distinction' (vol 1, 74). Nevertheless, significant distinctions remained which were noticed by the mainly female expert consumers - and Henry Tilney, of course!

\section{JACKIE REID-WALSH}

McGill University 


\section{Notes}

1 According to Dr. Burney's diaries Evelina was written during 1775-1776 (qtd. in Evelina 345ff). According to Austen's 'Advertisement,' Northanger Abbey was revised and completed in 1803 . She ends her note with an entreaty to the public to be lenient to the changes in 'places, manners, books, and opinions' that have occurred between completion and publication, as well as the interval from the original conception ([11]). The details of ball dresses that are given, such as high feathers and trains, are consistent with the fashion of 1803 .

2 Here I adapt the ideas of Peter Corrigon in 'Interpreted, circulating, interpreting: The Three dimensions of the clothing object' in The Socialness of Things: Essays on the Socio-Semiotics of Objects, ed. Stephen Riggins (1994), 435-50. Corrigon discusses three dimensions of the clothing object. The first is the public object revealing various social and cultural attributes. The second dimension concerns the piece of clothing as an object to which things happen within a political economy. The third dimension is how clothing can provoke things to happen, and is a kind of interpreter.

3 According to Ashelford, an embargo had been placed on the importing of French silk fabric in 1766, although there was considerable traffic in illicit goods. It took between three to six weeks to prepare the looms, and the mercers restricted the weavers to making a small number of pieces of a pattern in order to ensure the exclusiveness of the pattern. At this stage, a single length of silk, which was $1 / 2$ ell wide, or between $191 / 2$ and 21 inches, would take $31 / 2$ days to produce a dress length of 14 yards. To place these prices in perspective, Ashelford cites from the Memoires and Letters of Lady Louisa Stuart; she calculated the income required to live in fashionable society and make appearances at court was at least 1500 to 1600 pounds a year, as opposed to a middle-class annual income of the $1780 \mathrm{~s}$ reported in the London Advertiser as 400 pounds, with 40 pounds being delegated to the husband's and wife's clothes (154-55).

4 The circulation of raw cotton ultimately depended on the three-way trade of manufactured goods for slaves and slaves for rum, sugar, indigo and cotton (Ashelford 172-73). Technology for manufacturing cotton in Britain developed considerably in the late Eighteenth Century. Inventions include Arkwright's spinning frame (1767), Hargreaves' spinning jenny (1770), and Crompton's spinning mule (1779). While printing on cotton had developed in Britain in the early Eighteenth Century, new technology later made beautiful prints available at a reasonable price to a broad range of consumers. In 1774 the Imported Cottons Act was passed to protect Lancashire and Scottish industries (Ashelford 168-72; see Breward and Lemire).

5 The Branghton girls would have been able to display themselves as easily as the products in the silversmith shop if their father had adapted the fashion in London shops of having wide windows to display wares to passers-by (McKendrick, Brewer, and Plumb 85; cf. Ashelford).

6 For a discussion of recent modifications of Veblen, see also Jean-Christophe Agnew in Consumption and the World of Goods edited by Brewer and Porter and the introduction by Ann Bermingham in The Consumption of Culture edited by herself and Brewer. For a feminist reading of female consumption in Burney's later novel Camilla (1796), see Elizabeth Kowaleski-Wallace, Consuming Subjects: Women, Shopping, and Business in the Eighteenth Century. 


\section{Works Cited}

Ashelford, Jane. The Art of Dress: Clothes and Society 1500-1914. London: National Trust, 1996.

Austen, Jane. Northanger Abbey. Ed. R. W. Chapman. Oxford: Clarendon, 1948.

Letters to her sister Cassandra and others. Ed. R.W. Chapman. London: Oxford UP, 1952.

Bermingham, Ann and John Brewer (eds.). The Consumption of Culture 1600-1800: Image, Object, Text. London: Routledge, 1995.

Bradfield, Nancy. Costume in Detail: 1730-1930. London: Harrap, 1968.

Breward, Christopher. The Culture of Fashion. Manchester: Manchester UP, 1995.

Brewer, John and Roy Porter (eds.). Consumption and the World of Goods. London: Routledge, 1993.

Burney, Frances. Evelina. Ed. Stewart J. Cooke. New York: Norton, 1998.

Corrigon, Peter. 'Interpreted, circulating, interpreting: The Three dimensions of the clothing object,' in The Socialness of Things: Essays on the Socio-Semiotics of Objects. Ed. Stephen Riggins. Berlin: Mouton de Gruyter, 1994. 435-50.

Kowaleski-Wallace, Elizabeth. Consuming Subjects: Women, Shopping and Business in the Eighteenth Century. New York: Columbia UP: 1997.

Lemire, Beverly. Dress, Culture and Commerce: The English Clothing Trade before the Factory 1660-1800. Basingstoke: Macmillan, 1997.

M., S.D. A Picture of the Changes of Fashion. NP: 1818.

. The Mirror of the Graces, or The English Lady's Costume. By a Lady of Distinction. New York: Wiley for Riley, 1818.

McKendrick, Neil, John Brewer, and J.H.Plumb. The Birth of a Consumer Society: The Commercialization of Eighteenth-Century England. Bloomington: Indiana UP, 1982.

Miller, Daniel. Material Cultures: Why some things matter. London: UCL Press, 1998. 